\title{
PEMODELAN SIMULASI SISTEM DINAMIK UNTUK MENINGKATKAN JUMLAH PENDAPATAN UNIT RAWAT INAP RUMAH SAKIT ISLAM SURABAYA A.YANI
}

\author{
Anwar Romadhon ${ }^{1}$, Erma Suryani \\ ${ }^{1,2}$ Departemen Sistem Informasi \\ ${ }^{1,2}$ Fakultas Teknologi Elektro Dan Informasi Cerdas, Institut Teknologi Sepuluh Nopember \\ E-mail: ${ }^{1}$ anwar_28romadhon@yahoo.co.id, ${ }^{2}$ erma.suryani@gmail.com \\ *Penulis Korespondensi
}

(Naskah masuk: 20 Januari 2020, diterima untuk diterbitkan: 27 April 2020)

\begin{abstract}
Abstrak
Perkembangan rumah sakit di Indonesia semakin meningkat, sejak tahun 2012 sampai 2018 mengalami peningkatan dengan rata - rata 5.2\%. Tentunya hal tersebut memiliki dampak terhadap daya saing yang lebih kompetitif. Kebijakan pemerintah Indonesia yang mengharuskan rumah sakit bekerja sama dengan Jaminan Kesehatan Nasional (JKN) guna pemerataan pelayanan kesehatan mempengaruhi jumlah pendapatan. Faktanya asuransi BPJS Kesehatan mengalami defisit anggaran yang nilainya sangat besar. Manajement rumah sakit harus mencari strategi dan kebijakan yang tepat dalam upaya memaksimalkan pendapatan khususnya di era JKN. Pembatasan jumlah kunjungan tidak mungkin dilakukan mengingat sebagian besar pasien berasal dari peserta BPJS Kesehatan. Tujuan penelitian ini dilakukan untuk menemukan kebijakan dan solusi yang tepat bagi rumah sakit untuk mendapatkan keuntungan finasial dalam kondisi defisitnya anggaran asuransi kesehatan. Penting informasi membuat manajemen rumah sakit berupaya untuk memanfaatkan teknologi informasi sebagai media untuk merancang strategi bisnisnya, simulasi komputer seperti pemodelan sistem dinamik mempu menggambarkan dan mensimulasikan sistem secara nyata yang mengacu pada data, sehingga pemangku kepentingan dapat memprediksi kondisi yang bisa terjadi dimasa depan. Hasil penelitian menunjukkan bahwasanya dengan merubah sistem pembayaran dari Fee For Services menjadi INA - Case Base Groups dapat memberikan keuntungan lebih bagi rumah sakit, hal ini dikarenakan tarif yang ditetapkan menyesuaikan dengan tarif rumah sakit di seluruh Indonesia. Temuan lain yang perlu diperhatikan adalah piutang pihak asuransi mengalami peningkatan, tentunya hal tersebut perlu perhatian lebih, serta bisa dijadikan bahan pertimbangan untuk mengubah sistem pembayaran karena sesuai hasil simulasi dapat memaksimalkan jumlah pendapatan . Lokasi penelitian di unit rawat inap, rumah sakit islam surabaya, diharapkan dari hasil pemodelan simulasi bisa dijadikan sebagai gambaran atau acuan bagi manajemen puncak rumah sakit dalam mengambil sebuah keputusan sebagai strategi bisnis.
\end{abstract}

Kata kunci: Pendapatan, Pemodelan, Simulasi, Sistem Dinamik, Asuransi, Rumah Sakit.

\section{MODELING OF DYNAMIC SYSTEM SIMULATION TO INCREASE THE AMOUNT OF INCOME OF ISLAMIC HOSPITAL SURABAYA A.YANI}

\begin{abstract}
Hospital development in Indonesia has increased, from 2012 to 2018 has increased by an average of 5.2\%.. Of course this has an impact on more competitive competitiveness. Indonesian government policy that requires hospitals to work closely with the National Health Insurance (JKN) in order to equalize health services affects the amount of revenue. The fact is that BPJS Health insurance has a very large budget deficit. Hospital management must find the right strategy and policy in an effort to maximize revenue, especially in the JKN era. Limiting the number of visits is not possible considering that most patients come from BPJS Health participants. The purpose of this study was to find the right policies and solutions for hospital to obtain financial benefits in the health insurance budget deficit. Important information makes hospital management strive to utilize information technology as media for designing business strategies, computer simulations such as dynamic system modeling can describe and simulate real systems that refer to data, so that stakeholders can predict conditions that can occur in the future. The results showed that by changing the payment system from Fee For Services to INA - Case Base Groups can provide more benefits for hospital, this is because the rates set adjust to hospital rates throughout Indonesia. Another finding that needs to be considered is that the insurance receivables have increased, of course
\end{abstract}


it needs more attention, and can be taken into consideration to change the payment system because according to the simulation results can maximize the amount of income. The location of research in the inpatient unit, Surabaya Islamic hospital, is expected from the results of simulation modeling can be used as an illustration or reference for top management of the hospital in making a decision as a business strategy.

Keywords: Income, Modeling, Simulation, System Dynamic, Insurance, Hospital.

\section{PENDAHULUAN}

Penggunaan teknologi informasi (TI) dalam layanan kesehatan terutama di Rumah Sakit sangat banyak difokuskan pada pendaftaran pasien, pengodean ulang / pengambilan catatan medis dan transaksi pembayaran (Itumalla. 2012). sistem informasi dan teknologi informasi (SI/TI) merupakan strategi yang digunakan untuk mencapai keberhasilan suatu organisasi (Yunita et al. 2018). Menurut (Bertho et al. 2017) teknologi berperan penting dalam melakukan sebuah inovasi - inovasi di segala bidang dengan tujuan mengoptimalkan layanan. Semua organisasi, termasuk rumah sakit harus mengembangkan strategi untuk menanggapi faktor lingkungan dan tantangan kompetitif. Teknologi informasi (TI) di bidang kesehatan telah dipergunakan sebagai alat yang dapat mengubah pemberian layanan kesehatan lebih cepat dalam meberikan informasi serta sebagai penunjang strategi bisnis yang mampu memberikan keperluan data administrasi untuk efisiensi pelayanan (J. Le et al. 2013).

Kualitas layanan menjadi bahan evaluasi untuk mendapatkan masukan dari customer terhadap pengalaman pelayanan rumah sakit. Customer lebih cerdas dan selektif dalam menuntut kualitas yang lebih baik dalam produk dan layanan, terlebih lagi terhadap perusahaan dibidang jasa (M. Lee, 2016). Upaya meningkatkan kualitas pelayanan serta mutu dalam memenuhi harapan customer, mampu memberikan prespektif positif, sehingga berpengaruh terhadap peningkatkan jumlah kunjungan customer yang berpeluang meningkatkan jumlah pendapatan finansial. Tantangan yang dihadapin rumah sakit di Indonesia yakni kerja sama dengan program - program pemerintah seperti Jaminan Kesehatan Nasional, tertundanya pembayaran tagihan peserta JKN berdampak terhadap kesehatan keuangan rumah sakit.

Pendapatan finansial rumah sakit terletak pada kinerja bisnis yang mampu dicapai dengan menjaga mutu dan kualitas layanan, perlakuan bisnis dibidang rumah sakit berbeda dengan perusahaan pada umumnya, tanggung jawab sosial dalam pelayanan kepada pasien memiliki peran penting terhadap hasil keuangan (Abbaspour et al. 2018).

Pesatnya perkembangan teknologi informasi merupakan alternative untuk mendapatkan gambaran di masa mendatang. Memodelkan serta mensimulasikan kebijakan - kebijakan yang dibuat bermanfaat untuk mengetahui keputusan yang diambil sudah tepat atau tidak. Sistem dinamik (SD) adalah metode untuk mendeskripsikan secara dinamis, memodelkan, mensimulasikan dan menganalisis sistem yang komplek (Guo et al. 2018). Pemodelan dan simulasi sistem dinamik merupakan metodologi yang tepat untuk memperoleh gambaran secara detail terkait pengambilan keputusan (MAI \& SMITH, 2018). Pemodelan system dynamic dapat digunakan sebagai alat untuk mengaevaluasi dampak jangka pendek dan jangka panjang dari kebijakan ataupun keputusan yang diambil sehingga memberikan informasi dengan jelas dimasa mendatang. (Hasan et al. 2015). Menurut (Kumar, 2014) Sistem dinamik dapat diterapkan ke berbagai situasi dinamis, dalam lingkungan yang kompleks seperti, sosial, ekonomi, manajerial, industri, kesehatan masyarakat dan sistem ekologi, dll.

Tujuan penelitian ini adalah menemukan kebijakan atau solusi baru yang dapat membantu rumah sakit dalam upaya memaksimalkan pendapatan di tengah kondisi asuransi BPJS Kesehatan yang mengalami defisit anggaran, diharapkan dari hasil tersebut bisa dijadikan sebagai strategi baru di era jaminan kesehatan nasional. Diharapkan hasil memanfaatkan simulasi komputer yaitu sistem dinamik tujuan tersebut bisa dicapai serta manajemen rumah sakit lebih siap dalam menghadapi permasalahan dimasa depan khususnya dalam hal keterlambatan proses claim biaya perseta asuransi

\section{METODE PENELITIAN}

Pembahasan di bab ini menjelaskan metode yang digunakan pada penelitian, baik dari setting lokasi penelitian, perkembangan rumah sakit di Indonesia, definisi sistem, pemodelan, tahapan simulasi serta sistem pembayaran yang digunakan rumah sakit di era Jaminan Kesehatan Nasional.

\subsection{Metode Penelitian}

Pada penelitian peningkatan pendapatan , peneliti menggunakan metode simulasi, melalui beberapa tahapan diantara :

1. Pendefisian sistem dalam bentuk diagram kausatik : pada tahapan pendefinisian sistem merupakan identifikasi variabel - variabel yang mempengaruhi jumlah pendapatan, kemudia digambar dalam bentuk diagram kausatik, diagram ini menjelaskan serta merepresentasikan sistem secara nyata.

2. Pengambilan data : adapun data yang digunakan pada penelitian ini sebagai berikut : 
$\checkmark \quad$ Data pendapatan unit rawat inap tahun 2015 $-2017$

$\checkmark$ Data kunjungan pasien unit rawat inap tahun $2015-2017$

$\checkmark$ Data pendapatan jaminan kesehatan nasional asuransi BPJS 2015 - 2016

3. Pembuatan diagram flow model : diagram yang menjelaskan alur pada sistem, model flow yang dibuat mengacu pada diagram kausatik.

\subsection{Validasi}

Setelah model simulasi sudah dibuat dan diverifikasi terkait kelengkapan data yang digunakan, tahap selanjutnya adalah validasi untuk diukur valid atau tidak. ada dua teori yang digunakan pada proses validasi yaitu teori Man Comparison dan Amplitude Variation Comparison.

\subsection{Sistem Dinamik}

Menurut (Chang, 2011) pendekatan sistem dinamik (SD) dapat membantu para peneliti mendapatkan wawasan tentang perubahan dinamis, Metode SD dapat mensimulasikan banyak perspektif serta memberikan solusi jangka panjang, masalah yang kompleks dapat disajikan dalam cara yang ringkas dan sistematis untuk membantu manajer menguasai masalah. Dengan menggunakan model simulasi, evaluasi efektivitas berbagai kebijakan dapat dinilai dalam kerangka kerja yang sama. Pemodelan simulasi telah menjadi alat penting dalam menetapkan implementasi strategis, analisis kebijakan dan desain di banyak bidang (Samah et al. 2015). Dalam hal ini, sistem dinamik dapat membantu pembuat kebijakan untuk memvisualisasikan secara efektif untuk memprediksi sesuatu yang tidak terduga bisa terjadi.

System Dynamics (SD) adalah metode untuk menyelidiki perilaku sistem yang kompleks dari satuan waktu ke waktu dengan mengubah seluruh sistem menjadi serangkaian stok dan aliran yang saling berhubungan yang saling mempengaruhi melalui loop umpan balik (Zomorodian et al., 2018). Sedangkan (Mbohwa et al., 2017) berpendapat bahwasannya pendekatan dengan sistem dinamik menggunakan causal loop dan stock flow diagram, di mana causal loop diagram mewakili hipotesis sebab akibat dari suatu sistem, sedangkan diagram aliran stok menggambarkan struktur aliran sistem. Di sisi lain, variabel stok menentukan status sistem pada titik waktu mana pun, sementara variabel aliran menggambarkan tingkat perubahan stok.

\subsection{RS Islam Surabaya A.Yani}

RS Islam Surabaya berada di bawah naungan Yayasan Rumah Sakit Islam Surabaya (YARSIS) . RS Islam Surabaya mulai beroperasi sejak tanggal 25 Maret 1975, dengan kapasitas 40 tempat tidur dan kelas rumah sakit termasuk tipe Madya (setara tipe
C). adapun fasilitas dan layanan yang ada di RS Islam Surabaya - A.Yani, diantara :

1. Instalasi Gawat Darurat

2. Instalasi Rawat Inap

3. Instalasi Rawat Jalan

4. Instalasi Rawat Khusus

Instalasi Rawat Inap :

Rawat Inap Bersalin

Rawat Inap Anak

Rawat Inap Dewasa

\subsection{BPJS Kesehatan}

BPJS Kesehatan merupakan lembaga milik negara (BUMN). Pemerintah memberi tugas penting dan berat pada BPJS Kesehatan untuk memberikan jaminan kesehatan bagi masyarakat di Indonesia tanpa terkecuali. BPJS Kesehatan resmi beroperasi pada 1 Januari 2014, program asuransi pemerintah indonesia ini sengaja dibentuk untuk melindungi, menjamin, serta pemerataan jangkauan pelayanan kesehatan. warga Indonesia di wajibkan untuk mendaftar sebagai peserta asuransi BPJS. Terbentuknya jaminan kesehatan diatur dengan landasan Hukum :

1. Undang-Undang Dasar 1945

2. Undang-Undang Nomor 40 Tahun 2004 tentang Sistem Jaminan Sosial Nasional.

3. Undang-Undang Nomor 24 Tahun 2011 tentang Badan Penyelenggara Jaminan Sosial.

Kebijakan kerja sama antara program pemerintah seperti asuransi BPJS kesehatan dengan rumah sakit indonesia tentunya merupakan hal positif dalam pemerataan jangkauan pelayanan kesehatan, namun dari sisi finansial kerja sama ini memberikan pengaruh terhadap keuangan rumah sakit mengingat jumlah peserta yang banyak, tercatat per 31 desember 2019 jumlah peserta JKN adalah 224.149.019, yang dipecah menjadi beberapa bagian yaitu PBI APBN, PBI APBD, PPN - PN, PPU - BU, PBPU - Pekerja Mandiri dan Bukan Pekerja.berikut pada gambar 2.1 merupakan data peserta JKN.

\section{Peserta Program JKN}

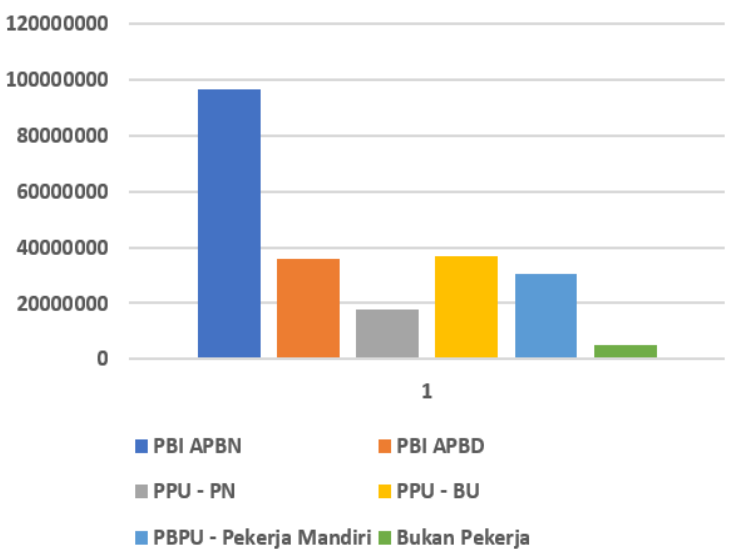

Gambar 1. Peserta BPJS (https://bpjs-kesehatan.go.id) updated 31 Maret 2020. 


\subsection{Rumah Sakit Indonesia}

Jumlah rumah sakit di indonesia semakin meningkat. sejak tahun 2012 sampai tahun 2018 terdapat peningkatan sebasar rata - rata 5.2\%. tentunya jika mengacu pada data tersebut maka manajemen rumah sakit memiliki pekerjaan rumah yang besar, manajemen harus mampu bertahan di persaingan yang kompetitif. Berikut pertumbuhan rumah sakit di Indonesia :

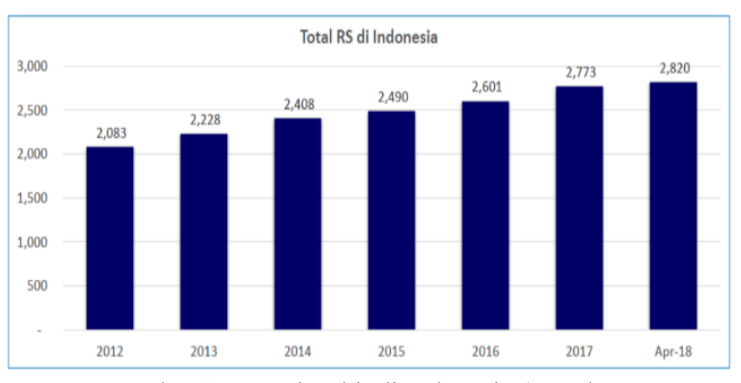

Gambar 2. Rumah sakit di Indonesia ( Sumber :

http://sirs.yankes.kemkes.go.id/rsonline/report/) updated April 2018

\subsection{Sistem Pembayaran BPJS Kesehatan}

Dalam sistem pembayaran yang ada dirumah sakit terdapat dua jenis yaitu retrospektif dan prospektif. Fee for services merupakan metode pembayaran rumah sakit berjenis retrospektif, dimana pembayaran ditetapkan setelah pelayanan kesehatan diberikan. Fee For Services adalah pembayaran berbasis pada tarif per jenis layanan dan ini lazim digunakan oleh seluruh rumah sakit dalam penetapan tarif mereka. sistem ini dinilai tidak efisien, karena diberikan kesempatan untuk menawarkan segala macam pelayanan kepada pasien, bahkan pelayanan kesehatan yang sebenarnya tidak perlu dilakukan. hal tersebut berakibat pada pemeriksaan yang berlebihan, resep obat yang terlalu banyak dan penggunaan alat medis yang berlebihan, sedangkan BPJS Kesehatan menggunakan sistem pembayaran per paket pelayanan yang mencakup seluruh komponen biaya rumah sakit, mulai dari pelayanan non medis hingga tindakan medis.

\subsection{SISTEM, PEMODELAN DAN SIMULASI}

Pada sub bab ini menjelaskan definisi sistem, pemodelan dan simulasi pada sistem dinamik.

\subsubsection{Sistem}

Dalam pemodelan dan simulasi, permasalahan yang diteliti akan dikonsepkan agar mampu merepresentasikan sistem nyata, sehingga sangat perlu memahami system secara mendetail. Menurut (Law, 1991) Kami mengategorikan sistem menjadi dua jenis, diskrit dan kontinu, Sistem diskrit adalah sistem yang variabel keadaannya berubah secara instan pada titik yang terpisah dalam waktu, sedangakan Sistem kontinu adalah sistem yang variabel-variabel statusnya berubah terus menerus sehubungan dengan waktu. Gambar berikut ini memetakan berbagai cara sistem dapat dipelajari (Yunita et al., 2018).

\subsubsection{Pemodelan}

Pemodelan merupakan representasi sistem secara nyata dalam bentuk variabel - variabel yang mempu menjelaskan keterkaitan satu sama lain. Pada bukunya yang berjudul Pemodelan \& Simulasi (Suryani, 2006) Secara skema pembuatan model dapat dilihat pada gambar 3 .

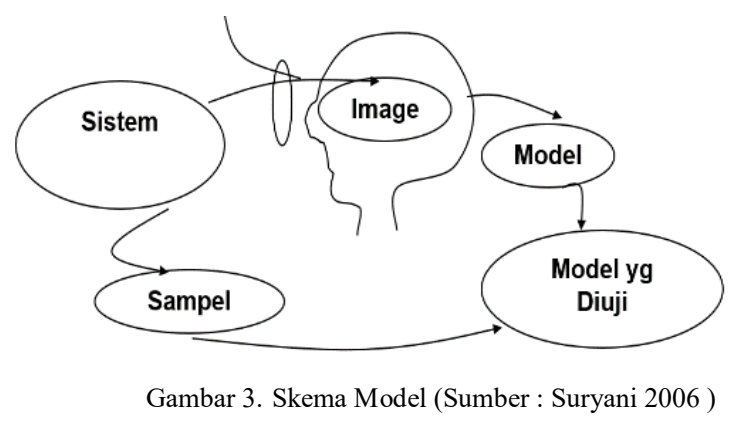

\subsubsection{Simulasi}

Proses simulasi merupakan tahapan dimana model yang dirancang akan dijalankan dengan simulasi komputer, semua varibel yang ada pada konsep akan diberi persamaan matematis sehingga dapat memberikan hasil simulasi sesuai perubahan yang diskenariokan, dengan hasil tersebut bisa dijadikan sebagai acuan dalam mengambil keputusan khusus bagi manajement puncak di rumah sakit.

\subsection{Tahapan Simulasi}

Pada bukunya yang berjudul Pemodelan \& Simulasi (Suryani, 2006) menyatakan ada tahapan tahapan untuk melakukan simulasi, diantaranya :

1. Pendefinisian system, langkah ini meliputi :

- Penentuan Batasan system

- Identifikasi variabel yang signifikan

2. Formulasi model : merumuskan hubungan antar variabel pada model yang di teliti.

3. Pengambilan data :identifikasi data yang diperlukan pada penelitian sesuai kebutuhan model.

4. Pembangunan model : menentukan jenis Bahasa simulasi yang digunakan untuk proses pemodelan.

5. Verifikasi model : proses pengecekan terhadap model apakah sudah bebas dari error.

6. Validasi model merupakan proses pengukuran dengan membandingankan data historis dengan data hasil simulasi, pengujian terhadap model bertujuan apakah model yang dibuat sudah sesuai dengan sistem nyata. Menurut (Barlas, 1989) dalam jurnalnya yang berjudul Multiple Test For Validation on Sistems Dynamics Type of Simulation Model, menjelaskan dua acara pengujian yaitu :

a.Perbadingan Rata - rata (Man Comparison)

$$
E 1=\frac{[\bar{S}-\bar{A}]}{\bar{A}}
$$


$\bar{S}=$ Nilai Rata-rata Hasil Simulasi

$\bar{A}=$ Nilai Rata-Rata Data

Model dianggap valid bila E $1 \leq 5 \%$

b. Perbandingan variasi Amplitudo (Amplitude Variation Comparison) adalah tahapan membandingkan variasi antara output simulasi dan data historis yang tersedia. Dua data tersebut dapat hitung standart deviasi model (Ss) dan standart model deviasi historis $(\mathrm{Sa})$ kedua standart deviasi ini kemudian dibandingakan menggunakan "Percent Error In The Variontons" atau E, adapun rumus sebagai berikut :

$$
E 2=\frac{[S s-S a]}{S a}
$$

- $\mathrm{Ss}=$ standard deviasi model

- $\mathrm{Sa}=$ standard deviasi data

Model dianggap valid bila $\leq 30 \%$

7. Skenario : merupakan penyusunan scenario atau strategi terhadap model, hal tersebut berguna untuk mendapatkan gambaran hasil ata kebijakan yang akan di ambil serta memperbaiki kinerja system.

\section{PEMBAHASAN HASIL DAN ANALISA}

Adapun analisa pembahasan pada penelitian ini diantara penggambaran diagram kausatik, diagram flow model, yaitu flow model pendapatan, pengeluaran dan asuransi. Fokus pembahasan pada jurnal ini terletak pada pengaruh pendapatan rumah sakit yang dipengaruhi oleh asuransi kesehatan.

\subsection{Diagram Kausatik}

Tahapan awal pada simulasi adalah membuat model konseptual yang digambarkan dengan causal loop diagram atau diagram kausatik.
Diagram ini digunakan untuk merepresentasikan sistem secara umum dan gambaran besar dari sistem tersebut, serta mejelaskan variabel - variabel apa saja yang mempengaruhi jumlah pendapatan unit rawat inap. Diagram kausatik ini disusun berdasarkan beberapa teori dai peneliti sebelumnya dan kondisi dilapangan yang menggambarkan sistem secara nyata, konseptual yang disusun dalam penelitian ini berdasarkan yaitu : Hospital Clínica Bíblica: Financial strategy for sustainable growth (Sanz, 2016), Financial Analysis of National University Hospitals (M. Lee, 2015), Dynamics of Financial System: A System Dynamics Approach (Nair, 2013), Pengaruh Jumlah Pasien BPJS Kesehatan Terhadap Pendapatan Rumah Sakit Umum Daerah dr. ABDUL RIVAI Kabupaten Berau (Purwaningsih \& Puspitasari, 2018), Pengembangan Model Simulasi Sistem Dinamik untuk Meningkatkan Pendapatan Unit Rawat Jalan Rumah Sakit RSI Jemursari Surabaya (Lusianik, 2015).

Tahapan selanjutnya adalah membuat diagram flow model (DFM) yang mengacu pada diagram kausatik, kemudian pada masing - masing variabel pada DFM dilakukan input data pendapatan dan asuransi yang sudah dihimpun oleh peneliti serta menentukan formula atau persamaan matematika untuk menghitung dan mengeluarkan hasil sehingga bisa divalidasi antara data asli dengan data simulasi apakah bisa dinyatakan valid atau tidak baik nilai E1 dan E2. sedangkan pada tahap akhir adalah skenario model untuk mencapai tujuan penelitian dengan menerapkan beberapa kebijakan yang disimulasikan untuk mengetahui hasilnya. Berikut model kausatik pada penelitian ini.

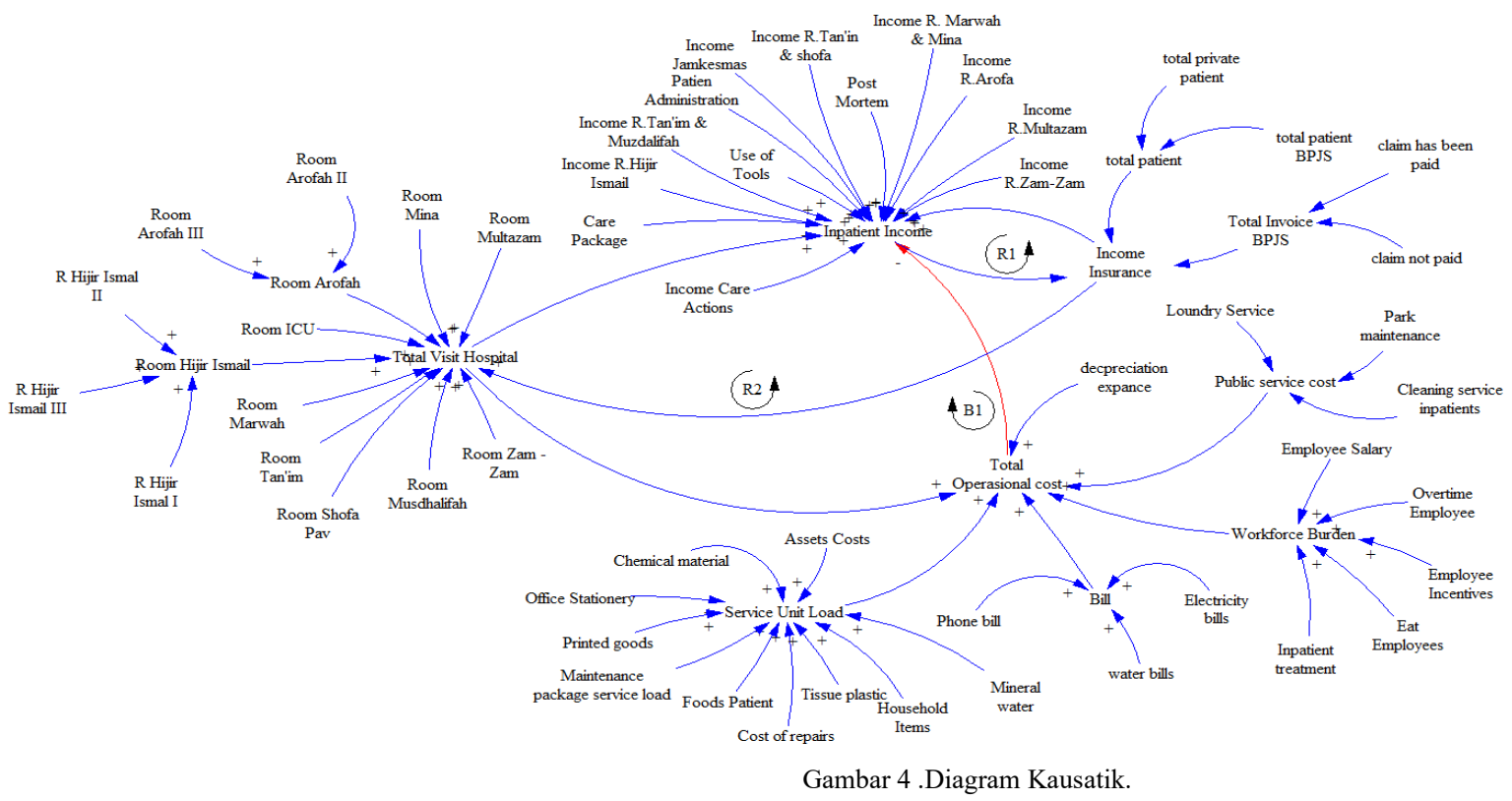




\subsection{Diagram Flow Model Pendapatan}

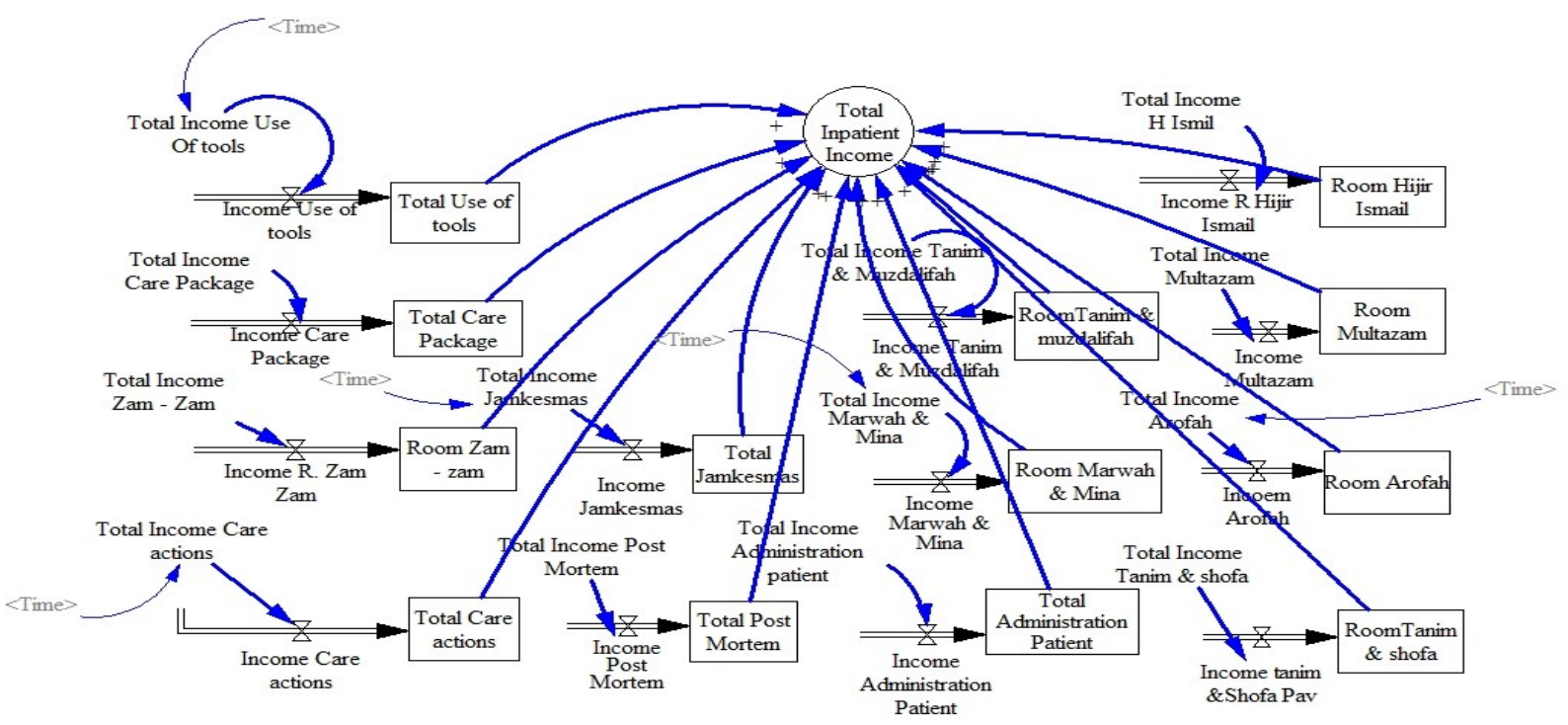

Gambar 5. Diagram Flow Pendapatan

Diagram flow model pendapatan mejelaskan terkait sumber pendapatan rumah sakit khususnya di unit rawat inap.

\subsection{Diagram Flow Model Asuransi}

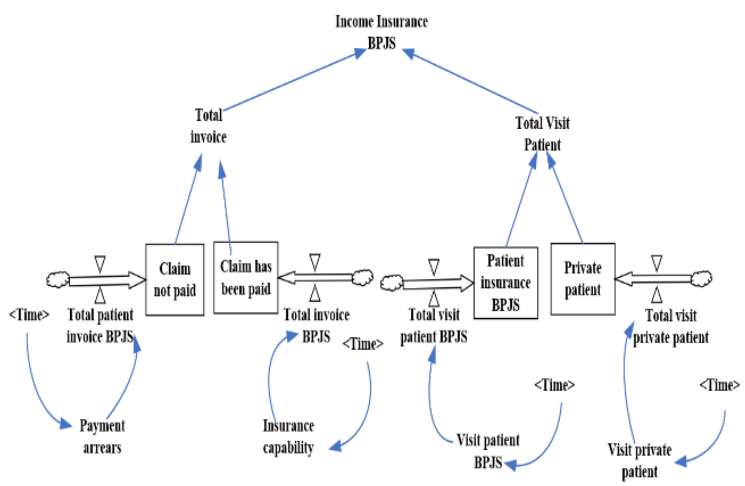

Gambar 6. Diagram Flow Asuransih

Diagram flow model asuransi merupakan fokus pembahasan dari penelitian ini, karena peneliti ingin mengetahui pengaruh kerja sama dengan asuransi BPJS, apakah dapat memaksimal upaya manajemen rumah sakit untuk meningkatkan pendapatan.

Dari diagram flow model pendapatan dan asuransi yang sudah di rancang, berikut kami sampaikan beberapa hasil validasi dengan menggunakan 2 metode diantaranya metode Man Comparison dan Amplitude Variation Comparison. Pengukuran validasi dengan kedua teori untuk menyatakan model yang dibuat dinyatakan valid atau tidak.
Hasil Validasi Diagram Flow Pendapatan :

Tabel 1. Hasil Validasi Post Mortem.

\begin{tabular}{ccc}
\hline \multicolumn{3}{c}{ income post mortem } \\
\hline keterangan & data asli & data simulasi \\
rate & 527679.8889 & 541043.6944 \\
stdev & 273753.4298 & 232198.7429 \\
e1 & $2.5 \%$ & \\
e2 & $15 \%$ & \\
\hline
\end{tabular}

Tabel 2. Hasil Validasi Care Actions.

\begin{tabular}{ccc}
\hline & income care actions \\
\hline keterangan & data asli & data simulasi \\
rate & 70234530.97 & 72496583.33 \\
stdev & 21472267.64 & 21566070.22 \\
e1 & $3.2 \%$ & \\
e2 & $0.4 \%$ & \\
\hline
\end{tabular}

Tabel 3. Hasil Validasi Room Arofah.

\begin{tabular}{ccc}
\hline \multicolumn{3}{c}{ income room arofah } \\
\hline keterangan & data asli & data simulasi \\
rate & 6694406.222 & 6991503.056 \\
stdev & 1912678.379 & 2140705.255 \\
e1 & $4.4 \%$ & \\
e2 & $12 \%$ & data simulasi \\
\multicolumn{4}{c}{ Tabel 4. Hasil Validasi Room Zam - Zam. } \\
\hline \multicolumn{4}{c}{ income room zam - zam } \\
\hline keterangan & data asli \\
rate & 9291010.306 & 9085212.222 \\
stdev & 2036112.109 & 1688321.365 \\
e1 & $2.2 \%$ & \\
e2 & $17 \%$ &
\end{tabular}

Hasil validasi diagram flow asuransi :

\begin{tabular}{ccc}
\multicolumn{3}{c}{ Tabel 5. Hasil Validasi Pendapatan BPJS. } \\
\hline \multicolumn{3}{c}{ income pendapatan asuransi BPJS } \\
\hline keterangan & data asli & data simulasi \\
rate & $4,197,433,182$ & $4,197,433,333$ \\
stdev & $873,207,466$ & $873,206,687$ \\
e1 & $0.000004 \%$ & \\
e2 & $0.000089 \%$ & \\
\hline
\end{tabular}


Tabel 6. Hasil Validasi Hutang BPJS

\begin{tabular}{ccc}
\hline \multicolumn{3}{c}{ hutang asuransi BPJS. } \\
\hline keterangan & data asli & data simulasi \\
rate & $1,022,415,088$ & $1,022,414,000$ \\
stdev & 341499807.6 & 341498258.2 \\
e1 & $0.0001 \%$ & \\
e2 & $0.0005 \%$ & \\
\hline
\end{tabular}

Tabel 7 Hasil. Validasi Room Zam - Zam. Pasien Pribadi

\begin{tabular}{ccc} 
& Pasien Pribadi & \\
\hline keterangan & data asli & data simulasi \\
rate & 144 & 149 \\
stdev & 35 & 25 \\
e1 & $4 \%$ & \\
e2 & $27 \%$ & \\
\hline
\end{tabular}

Tabel 8. Hasil Validasi Room Zam - Zam.

\begin{tabular}{ccc}
\hline \multicolumn{3}{c}{ Pasien BPJS } \\
\hline keterangan & data asli & data simulasi \\
rate & 904 & 904 \\
stdev & 217 & 217 \\
e1 & $0.00028 \%$ & \\
e2 & $0.00168 \%$ & \\
\hline
\end{tabular}

\subsection{SKENARIO MODEL}

Dalam meprediksi kejadian dimasa mendatang pada tahap skenario model, ada 3 skenario yang dibuat, yaitu Prediksi skenario kebijakan kerja sama dengan asuransi BPJS Kesehatan, prediksi skenario hutang asuransi dan skenario implementasi sistem pembayaran INA - Case Base Groups. Model skenario yang di ujicoba menggunakan data rumah sakit, sehingga hasil yang didapatkan menggambarkan sistem secara nyata. Berikut diagram flow model untuk ke 3 skenario yang diusulkan dalam penelitian ini, sebagai berikut :

\subsubsection{Prediksi Skenario kebijakan kerja sama dengan asuransi BPJS}

Dalam skenario ini peneliti memanfaatkan data pendapatan yang sudah dihimpun, kemudian dilakukan analisa Forecasting yang merupakan sebuah teknik analisa perhitungan dengan pendekatan kuantitatif untuk memprediksi kejadian masa depan berdasarkan referensi data pendapatan asuransi BPJS dimasa lalu (data 2015 -2017). berikut model flow diagramnya :

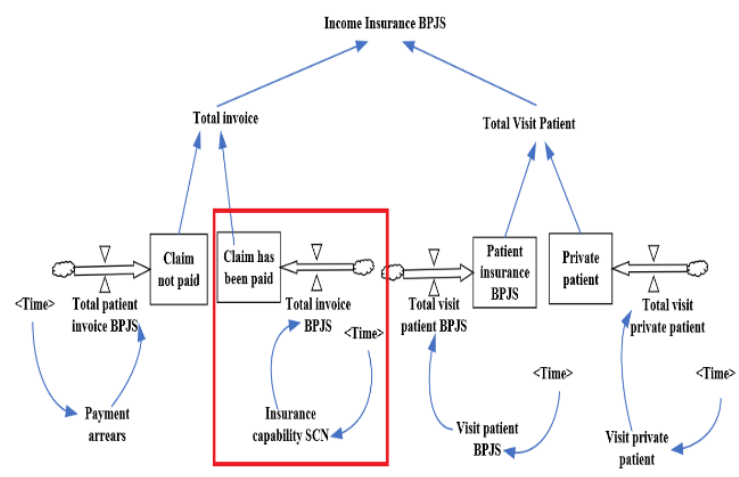

Gambar 7. Skenario Model Insurance Capability

\subsubsection{Prediksi skenario hutang BPJS}

Analisa Forecasting juga digunakan pada skenario untuk memprediksi jumlah hutang asuransi BPJS yang mengalami peningkatan, hal tersebut perlu perhatian dan analisa yang lebih karena mempengaruhi keadaan keuangan rumah sakit. berikut model flow diagramnya :

Gambar 8. Prediksi Model Payment Arrears

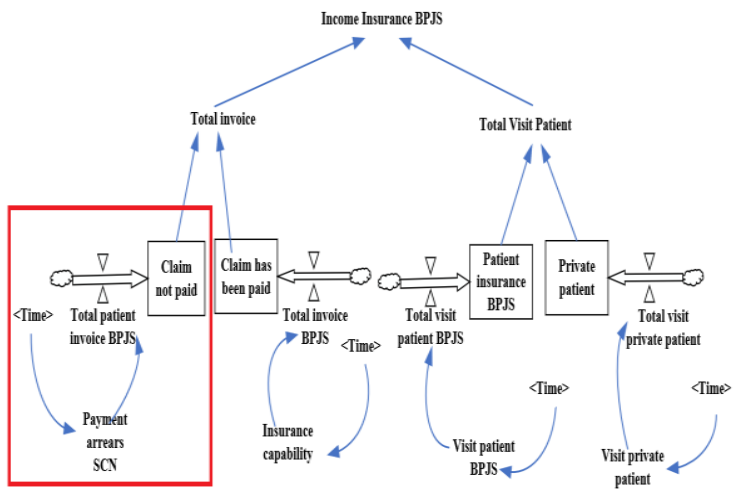

\subsubsection{Skenario Implementasi sistem pembayaran Indonesia - Case Based Groups (INA - CBGs)}

Pihak manajement rumah sakit harus paham dan mengerti bahwa sesuai analisa data pada penelitian ini bahwa sebagian besar jumlah kunjungan pasien dan jumlah pendapatan berasal dari peserta asuransi BPJS Kesehatan. INA - CBGs merupakan sistem pembayaran tarif paket pelayanan kesehatan yang mencakup seluruh komponen biaya rumah sakit, mulai dari pelayanan non medis hingga tindakan medis. Pada umumnya sistem pembayaran pada rumah sakit ditentukan setelah pelayanan kesehatan selesai namun pada era JKN, sistem pembayaran dibalik dimana tarif pelayanan kesehatan telah ditetapkan sebelum pelayanan kesehatan diberikan kepada pasien. Skenario model ini bertujuan untuk meningkatkan jumlah pendapatan rumah sakit yang secara langsung berkaitan dengan kebijkan kerja sama dengan asuransi khususnya di era jaminan kesehatan nasional (JKN). Penerapan sistem pembayaran INA-CBG's juga dapat mendorong manajement rumah sakit untuk dapat melakukan pelayanan kesehatan secara efektif, efisien. Berikut skenario flow model yang dirancang.

Hasil dari model skenario tersebut dapat meningkatkan jumlah pendapatan. mengacu pada data penelitian bahwasannya dengan menerapkan sistem pembayaran Fee For service rata - rata pendapatan sebesar Rp. 422,342,500. Sedangkan dengan mengubah sistem pembayaran dari Fee For Services menjadi INA - CBGS mulai tahun 2017 sampai 2020 mengalamin peningkatan dengan rata rata pendapatan sebesar Rp . 1,152,395,056. maka dari hasil skenario yang diuji coba pada software simulasi, layak dijadikan bahan pertimbangan bagi manajemen rumah sakit. 


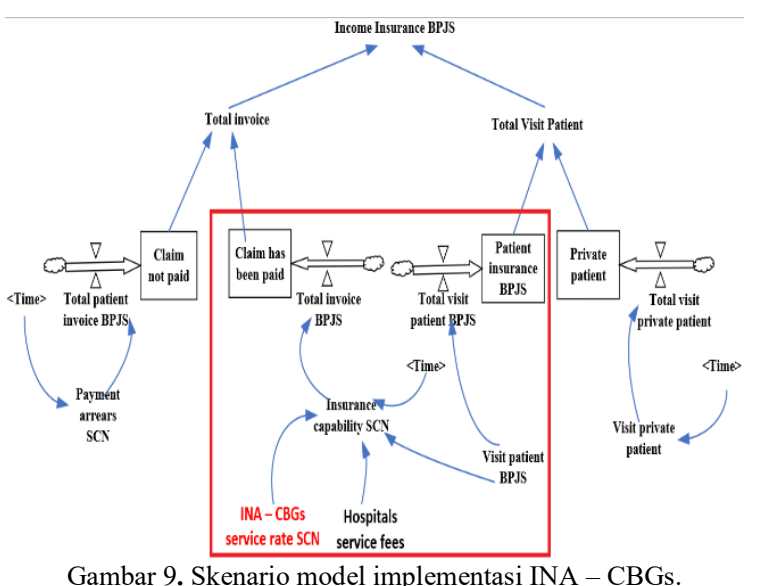

\section{KESIMPULAN DAN SARAN}

Hasil simulasi menunjukkan bahwa kebijakan kerja sama dengan jaminan asuransi kesehatan, dapat dimaksimalkan dengan merubah sistem pembayaran, sehingga upaya meningkatkan jumlah pendapatan bisa dicapai, hal tersebut bisa dijadikan sebagai acuan manajement rumah sakit untuk mengambil keputusan, adapaun kesimpulan dari masing - masing kebijkan sebagai berikut :

1. Kebijakan kerja sama dengan jaminan kesehatan nasional seperti Asuransi BPJS Kesehatan memberikan pengaruh yang baik terhadap upaya peningkatan pendapatan rumah sakit, dari hasil skenario model untuk 36 bulan kedepan dengan asumsi pola data pendapatan BPJS tahun 2015 - 2017 terjadi peningkatan, sebelumnya rata - rata pendapatan BPJS sebesar Rp. 4,197,433,182 perbulan meningkat dengan rata - rata RP. $6,728,680,395$ perbulan.

2. Hal yang perlu diperhatikan terkait kebijakan kerja sama dengan jaminan kesehatan nasional seperti Asuransi BPJS Kesehatan adalah masalah hutang atau tunggakan biaya peserta asuransi, tahun 2015 sampai 2017 rata - rata hutang BPJS sebesar Rp. 1,022,415,088 kemudian setelah disimulasikan 36 bulan kedepan meningkat dengan rata - rata RP. 2,205,702,655 perbulan.

3. Sebagai kebijakan untuk meningkatkan jumlah pendapatan rumah sakit, maka diusulkan sebuah strategi dengan mengubah sistem pembayaran Fee For Services menjadi INA - CBGs, hasil simulasi menunjukan terjadi peningkatan pendapatan yang sebelumnya rata - rata pendapatan sebesar Rp. 422,342,500 meningkat dengan rata - rata $\mathrm{Rp}$. $1,152,395,056$.

Adapun beberapa saran yang bisa dijadikan bahan pertimbangan apabila ada peneliti yang ingin melanjutkan dan mengembangkan lebih lanjut adalah sebagai berikut :
1. Model simulasi akan mendapatkan pembahasan mendatail apabila ditambahkan jumlah pengeluaran khusus pasien asuransi, sehingga bisa akumulasi pendapatan bersih dari jaminan kesehatan Indonesia.

2. Model simulasi akan mendapatkan pembahasan lebih detail apabila ditambahkan jumlah kebutuhan logistic rumah sakit yang mampu memberikan penjelasan terkait jumlah kebutuhannya, jumlah pemakaian, dan sisa persediaan barang yang berhubungan dengan keperluan rumah sakit. Mengingat pada penelitian ini banyak kekurangan dan tidak ada data yang pasti untuk menekan biaya operasional khusus dibagian logistik. Tentunya hal diatas bisa dijadikan pertimbangan apabila penelitian ini ingin dilanjutkan agar mendapatkan hasil yang lebih baik

\section{DAFTAR PUSTAKA}

ABBASPOUR, H., DREBENSTEDT, C., BADRODDIN, M., \& MAGHAMINIK, A. (2018). International Journal of Mining Science and Technology Optimized design of drilling and blasting operations in open pit mines under technical and economic uncertainties by system dynamic https://doi.org/10.1016/j.ijmst.2018.06.009

BARLAS, Y. (1989). Multiple tests for validation of system dynamics type of simulation models *, 42, 59-87.

BERTHO, M., ANDEKA, ROCKY, T., \& MELKIOR, NIKOLAR, NGALUMSINE, S. (2017). Analisa Kinerja Sistem Informasi dan Teknologi Informasi Untuk Menunjang Kinerja Karyawan Menggunakan Framework IT Balanced Scorecard (Studi Kasus Pada WI-FI Universitas Kristen Satya Wacana), 4(4), 318332. https://doi.org/10.25126/jtiik.201744499

CHANG, W.-L., \& CHANG, H.-C. (2011). A Dynamic System of E-Service Failure, Recovery, and Trust.

GUO, Q., WANG, E., NIE, Y., \& SHEN, J. (2018). Pro fi t or environment? A system dynamic model analysis of waste electrical and electronic equipment management system in China. Journal of Cleaner Production, 194, 34-42.

https://doi.org/10.1016/j.jclepro.2018.05.112

HASAN, N., SURYANI, E., \& HENDRAWAN, R. (2015). Analysis of Soybean Production And Demand to Develop Strategic Policy of Food Self Sufficiency: A System Dynamics Framework. Procedia - Procedia Computer Science, 72, 605-612. https://doi.org/10.1016/j.procs.2015.12.169

ITUMALLA, R. (2012). Information Technology and 
Service Quality in Health Care : An Empirical Study of Private Hospital in India, 3(4), 1-4.

KUMAR, D. (2014). Modelling rural healthcare supply chain in India using system dynamics. Procedia Engineering, 97, 2204-2212. https://doi.org/10.1016/j.proeng.2014.12.464

LAW, A. M. (1991). SIMULATION ANALYSIS.

LEE, J., MCCUllOUGH, J. S., \& TOWN, R. J. (2013). The impact of health information technology on hospital productivity, 44(3), 545-568.

LEE, M. (2015). Financial Analysis of National University Hospitals in Korea. Osong Public Health and Research Perspectives, 6(5), 310317. https://doi.org/10.1016/j.phrp.2015.10.007

LEE, M. (2016). Competitive Strategy for Successful National University Hospital Management in the Republic of Korea. Osong Public Health and Research Perspectives, 7(3), 149-156. https://doi.org/10.1016/j.phrp.2016.02.002

LUSIANIK, F. (2015). Pengembangan Model Simulasi Sistem Dinamik untuk Meningkatkan Pendapatan Unit Rawat Jalan Rumah Sakit ( Studi Kasus : RSI Jemursari Surabaya ), 1-6.

MAI, T., \& SMITH, C. (2018). Scenario-based planning for tourism development using system dynamic modelling: A case study of Cat $\mathrm{Ba}$ Island , Vietnam. Tourism Management, 68(April 2016), 336-354. https://doi.org/10.1016/j.tourman.2018.04.005

MBOHWA, C., ANDRI, I., PINA, A., FERRAO, P., FOURNIER, J., LACARRIERE, B., \& CORRE, O. LE. (2017). System dynamics archetypes for capacity management of energy System. Energy Procedia, 141, 199-205. https://doi.org/10.1016/j.egypro.2017.11.038

NAIR, G. K. (2013). Dynamics of Financial System : A System Dynamics Approach, 3(1), 14-26.

PURWANINGSIH, \& PUSPITASARI, L. (2018). ECO-BUILD; Economy Bring Ultimate Information All About Development Journal EISSN: 2620-5416 PISSN: 2622-5336, 2(2), 42-52.

SAMAH, A. A., WAH, L. K., ISHAK, M., MAJID, H. A., \& MOHD, N. F. (2015). Decision Support System Using System Dynamics Simulation Modelling for Projection of Dentist Supply, $22-25$. https://doi.org/10.1109/CASH.2014.18

SANZ, L. (2016). Hospital Clínica Bíblica : Financial strategy for sustainable growth is. Journal of Business Research, 69(9), 3905-3909. https://doi.org/10.1016/j.jbusres.2015.11.023

YUNITA, U., ADI, N., \& AGUSTINUS, F. W. (2018). Perencanaan Strategis Sistem Informasi dan Teknologi Informasi Pada Dinas
Perindustrian dan Tenaga Kerja Kota Salatiga., 5(3). https://doi.org/10.25126/jtiik.201853655

ZOMORODIAN, M., HIN, S., HOMAYOUNFAR, M., IBRAHIM, S., EHSAN, S., \& EL-SHA, A. (2018). The state-of-the-art system dynamics application in integrated water resources modeling, 227(September), 294304.

https://doi.org/10.1016/j.jenvman.2018.08.097 
Halaman ini sengaja dikosongkan 